\title{
Cartography, War Correspondence and News Publishing: The Early Career of Nicolaes van Geelkercken, 1610-1630*
}

\author{
Helmer Helmers
}

In the first decades of the seventeenth century, Amsterdam quickly developed into the main centre of the European book trade. "The miracle of the world", according to some, the growth was indeed remarkable. When Cornelis Claesz opened his shop in 1578, competition was insignificant. When he died, in 16o9, thirty booksellers populated the city. In 1621, the number had grown to fifty. ${ }^{2}$ By the middle of the century, the book trade had expanded to such an extent that, according to the famous estimate by De la Fontaine-Verweij, about thirty per cent of all the books published in Europe were produced in the once insignificant backwater where Claesz had begun his career. ${ }^{3}$ And as they developed into both the staple market and the bookshop of the world, Amsterdam and the dense network of Dutch cities surrounding it also became the prime information hub of Europe, where continental, British, Atlantic and oriental networks met. ${ }^{4}$

* This article is part of my research programme Reporting the Thirty Years War in the Dutch Media, 1618-1648, which is financed by the Netherlands Organisation for Scientific Research (Nwo). I thank Elmer Kolfin for commenting on a draft version of this article, and Kees Zandvliet for his suggestions at an earlier stage.

1 Paul Hoftijzer, 'Metropolis of Print. The Amsterdam Book Trade in the Seventeenth Century', in Urban Achievement in Early Modern Europe. Golden Ages in London, Antwerp, and Amsterdam, ed. Patrick O'Brian (Cambridge: Cambridge University Press, 2001), pp. 249-63; Lotte Hellinga, ed., The Bookshop of the World. The Role of the Low Countries in the Book-trade, 1473-1941 (Utrecht: Hes \& De Graff, 2001).

2 Claartje Rasterhoff, 'Carrière en concurrentie in een culturele sector. De Amsterdamse boekhandel, 1580-180o', De Zeventiende Eeuw, 27.2 (2011), pp. 162-79, at 162.

3 Herman de la Fontaine Verwey, 'Het Hollandse wonder', in Boeken in Nederland. Vijfhonderd jaar schrijven, drukken en uitgeven, ed. P.F.J. Obbema (Amsterdam: Koninklijk Verbond van Grafische Ondernemingen, 1979), pp. 46-64.

4 Siegfried Huigen and Jan de Jong, eds., The Dutch Trading Companies as Knowledge Networks (Leiden: Brill, 2010); Clé Lesger, Handel in Amsterdam ten tijde van de Opstand. Kooplieden, commerciële expansie en verandering in de ruimtelijke economie van de Nederlanden ca. 1550-ca. 1630 (Hilversum: Uitgeverij Verloren, 2001), pp. 209-49.

(C) HELMER HELMERS, 2016 | DOI 10.1163/9789004277199_016

This is an open access chapter distributed under the terms of the Creative Commons Attribution-

Noncommercial-NoDerivatives 3.o Unported (CC-BY-NC-ND 3.o) License. 
In this fertile, but extremely competitive environment, the careers of various prominent news publishers took shape. The Truce Period of 16o9-21 was especially crucial for the development of a stable news market. Already before the armistice various booksellers moved to Amsterdam from exile elsewhere in Europe, and after 1609 others followed. ${ }^{5}$ Prominent news publishers to be, such as Claes Jansz Visscher, carved out their place in the market of topical print in this period. ${ }^{6}$ The Truce also brought fundamental changes to the kind of news that was published. In the preceding decades, Dutch news publishing had been dominated and structured by the war against Spain: major news houses, such as the Hogenberg firm in Cologne, had developed as part of the Orange war propaganda machine. ${ }^{7}$ Peace now threatened this war trade. The army correspondent Broer Jansz complained in 1609 that he had to "stay home because of the Treves" (i.e. the armistice between Spain and the United Provinces). Luckily for Jansz, growing tensions in Germany created new opportunities. He was delighted that the "brave preparations for battle" in Jülich allowed him to go the front again, and report war news to the undefined "masters" whom he had served as an informer before. ${ }^{8}$ Throughout the Truce, the widening conflict in Germany provided Dutch newsmakers with an alternative, steady supply of news, which was eagerly exploited. The temporary public sphere created by the Truce conflicts in the late 1610 s would give another major boost to the market for topical print, leading to "a tidal wave of pamphlets" in 1616-19. ${ }^{9}$ But it was largely German news, often translated from German sources, that enabled newsmakers to engage in consistent news production,

5 For example Francois van der Hoeye (1610) and Crispijn van de Passe (1611). Cf. Rasterhoff, 'Carrière en concurrentie'.

6 Nadine Orenstein, Huigen Leeflang, Ger Luijten and Christiaan Schuckman, 'Print Publishers in the Netherlands 1580-1620', in Dawn of the Golden Age. Northern Netherlandish Art 1580-1620, ed. Ger Luijten et al. (Zwolle: Rijksmuseum with Waanders publishing, 1993), pp. 167-200, at 194.

7 Christi Klinkert, Nassau in het Nieuws. Nieuwsprenten van Maurits van Nassau's militaire ondernemingen uit de periode 1590-16oo (Zutphen: Walburg Pers, 2005). On the earlier Nassau propaganda, see e.g. René van Stipriaan, 'Words at War. The Early Years of William of Orange's Propaganda', Journal of Early Modern History, 11.4-5 (2007), pp. 331-49.

8 Henk Borst, 'Broer Jansz in Antwerpse ogen. De Amsterdamse Courantier na de slag bij Kallo in 1638 neergezet als propagandist', De Zeventiende Eeuw, 25.1 (2009), pp. 55-89, at 79.

9 Craig E. Harline, Pamphlets, Printing, and Political Culture in the Early Dutch Republic (Dordrecht: Springer, 1987), p. 9. See also Roeland Harms, Pamfletten en publieke opinie. Massamedia in de zeventiende eeuw (Amsterdam: Amsterdam University Press, 2011); Marika Keblusek, Boeken in de Hofstad. Haagse boekcultuur in de Gouden Eeuw (Hilversum: Uitgeverij Verloren, 1997), p. 38 . 
and which allowed Broer Jansz and Caspar van Hilten to establish their corantos in $1618 / 19 .{ }^{10}$

It is remarkable that we know relatively little about this formative period, when several publishers laid the foundations for famous publishing houses that would come to dominate the European news market. These were the people who actually made the Dutch news entrepôt, but their lists, their sources, their networks and their marketing strategies remain largely unstudied. Unlike newsmakers such as Abraham Verhoeven, Richard Verstegan, and Théophraste Renaudot, whose lives and work have been well studied, we know relatively little about their influential Dutch competitors or predecessors such as Jansz, Van Hilten, Visscher, and the many enterprising, but largely forgotten minor news publishers and authors who contributed to the Dutch news boom of the first decades of the seventeenth century. ${ }^{11}$

The main reason for this lacuna is the fact that scholarship on early seventeenth-century Dutch publishers has traditionally been fragmented along disciplinary lines that obscure our understanding of their businesses and careers. ${ }^{12}$ The early courantiers Broer Jansz, Caspar van Hilten and Jan Jansz sr. appear in histories and bibliographies of the newspaper not as the versatile all-rounders that they were, but as the publishers of the earliest Dutch newspapers only - as if their corantos appeared in a different universe from their non-periodical publications. ${ }^{13}$ Other publishers, such as Visscher and Johannes Janssonius have been studied predominantly for their most famous, and qualitatively superior work: news and art engravings in the case of the former, and maps in the case of the latter. Although these approaches have great value for the subject specialist, they are of limited use to the historian of seventeenth-century news or print. The more recent trend to study news

$10 \quad$ Annie Stolp, De eerste couranten in Holland (Haarlem: J. Enschedé en zonen, 1938), p. 73.

11 On Renaudot, see Howard M. Solomon, Public Welfare, Science and Propaganda in Seventeenth Century France: The Innovations of Théophraste Renaudot (Princeton: Princeton University Press, 1972), and Stéphane Haffemayer, L'information dans la France du XVIIe siècle: la Gazette de Renaudot de 1647 à 1663 (Paris: Honoré Champion, 2002). On Verstegan, Paul Arblaster, Antwerp and the World. Richard Verstegan and the International Culture of Catholic Reformation (Leuven: Leuven University Press, 2004). On Verhoeven: Paul Arblaster, From Ghent to Aix: How They Brought the News in the Habsburg Netherlands 1550-170o (Leiden: Brill, 2014).

12 Cf. Djoeke van Netten, 'Een boek als carrièrevehikel. De zeemansgidsen van Blaeu', De Zeventiende Eeuw, 27.2 (2011), pp. 214-231.

13 Folke Dahl, Dutch Corantos 1618-1650. A Bibliography. Illustrated with 334 Facsimile Reproductions of Corantos Printed 1618-1625 and an Introductory Essay on 17th Century Stop Press News (The Hague: Koninklijke Bibliotheek, 1946). 
sources as part of heterogeneric politico-religious discourses and debates has mended the fragmented image of the sources, but likewise kept the newsmakers and their lists largely out of view. ${ }^{14}$

Important questions therefore remain unanswered. What did the early careers of the people that actually made the Dutch Republic into the information capital of early modern Europe look like? What was the role of news within publishers' wider lists, and how did they market the news? In which networks did they participate? Only once we understand the ways in which individual publishers handled the news and how they responded to the opportunities and demands of local, national and international markets, can we start to compare careers and strategies, both nationally and internationally. It is partly through case studies, then, that we can gain insight into the development of the Dutch news industry in the 1610 s and 1620 .

In order to study the careers of early seventeenth-century publishers and printers, we need to chart and analyse their lists, combine the expertise from various disciplines, and trace the scarce archival material available. For the bigger and long-lived publishing houses such as Visscher's, this would require long-term research projects, like Paul Arblaster's work on Richard Verstegan, or Ilja Veldman's on the De Passe family. ${ }^{15}$ But it is instructive as well to focus on smaller cases: on the minor, largely forgotten publishers, who also took their chances on the news market, but were less successful in the long run. Among this large group of minor news entrepreneurs we find the experimenters and the occasional radicals that provided the market with the dynamism required for the ultimate success of others.

This chapter focuses on one of those lesser-known characters in the news trade, Nicolaes van Geelkercken $\left(15^{8} 5^{-1656)}\right.$. Trained as a cartographer and an engraver, Van Geelkercken specialized in maps. Because of the quality of his maps, and his later career as a surveyor of the province of Guelders, his work has been studied exclusively by historians of cartography, who have focused on his later work for reasons of quality or an interest in local history. ${ }^{16}$ Like so

14 Elmer Kolfin, 'Amsterdam: Stad van prenten. Amsterdamse prentuitgevers in de 17de eeuw', in Gedrukt tot Amsterdam. Amsterdamse Prentmakers en-Uitgevers in de Gouden Eeuw, ed. Elmer Kolfin and Jaap van der Veen (Zwolle: Uitgeverij WBOOKS, 2011), pp. 10-57; Ad Leerintveld, 'Politiek, religie en literatuur. Het fonds van de Haagse drukker en uitgever Aert van Meurs en de familie Huygens', De Zeventiende Eeuw, 8.2 (1992), pp. 139-47.

15 Arblaster, Antwerp and the World; Ilja Veldman, Crispijn de Passe and his Progeny (1564-1670). A Century of Print Production (Rotterdam: Sound \& Vision, 2001). See also Van Netten, 'Een boek als carrièrevehikel'.

16 See: J. Keuning, 'Nicolaas Geelkerken', Imago Mundi 11.1 (1954), pp. 174-7; M.M. DoorninkHoogenraad, et al., Nicolaes van Geelkercken. Een Gelders cartograaf uit de zeventiende 
many of his fellow-newsmakers, then, Van Geelkercken is known for only one aspect of his professional life. ${ }^{17}$ Yet before he settled in Guelders, Van Geelkercken had been a versatile book professional, an all-round newsman who not only illustrated, but also wrote, translated, printed, and published the news, especially news maps. Little is known about the practice of seventeenthcentury news cartographers, especially in this early period. ${ }^{18}$ Van Geelkercken's case offers a unique possibility to gain insight into the genesis of this prominent genre. His case is instructive, moreover, because for all his idiosyncrasies, he is also a typical example of the enterprising, experimenting pioneers who transformed the industry in this period.

\section{An Incidental Beginning: From Cartography to War News}

Van Geelkercken was born near Geilenkirchen, a town in the strategically important duchy of Jülich, or Juliers, just across the Dutch border. ${ }^{19}$ Before he started his career as a news publisher, he had worked for several years as a cartographer, engraver and colourer of maps ('af-setter') in Amsterdam, presumably in the shop of Jodocus Hondius. His career as a news publisher began by accident. In 1610, just when he was setting up his business in Amsterdam, Jülich became the subject of a succession conflict that turned into a confessional struggle involving all the major European powers. ${ }^{20}$ With all the eyes of Europe aimed at his fatherland, Nicolaes was suddenly in the perfect position to provide information that a wide European audience now craved. He was not a man to ruin such a chance.

eeuw (Zutphen, 1972); Peter H. Meurer, 'De jonge Nicolaes van Geelkercken', Caertthresoor, 20.2 (2001), pp. 41-7. In this aspect, his case is similar to that of Willem Jansz Blaeu. Cf. Van Netten, 'Een boek als carrièrevehikel'.

17 Cf. M.E. van der Meulen, 'Nicolaes Geijlkerck', Oud Holland, 18 (190o), pp. 45-68, at 45-7.

18 Cf. Ruben van Luijk, 'Maps of Battles, Battle of Maps: News Cartography of the Battle at Neerwinden, Flanders, 1693', Imago Mundi, 60.2 (2008), pp. 211-20, at 211, 218.

19 Various scholars have supposed that Van Geelkercken was born in Scherpenzeel, in Guelders. See e.g. Doornink-Hoogenraad, Nicolaes van Geelkercken, pp. 7-9 and Eddy K. Grootes, ed., Wonderlicke avontuer van twee goelieven (Muiderberg, 1988), p. 54. Hollstein has Zutphen as the town of his birth: Friedrich Wilhelm Hollstein, Hollstein's Dutch \& Flemish etchings, engravings and woodcuts ca. 1450-170o, vol. 7 (Amsterdam: Hertzberger, 1953), p. 91. Meurer, 'De jonge Nicolaes van Geelkercken', has shown conclusively that he was actually born in the village of Geilenkirchen near Jülich.

Alison D. Anderson, On the Verge of War, International Relations and the Jülich-Kleve Succession Crises (1609-1614) (Leiden: Brill, 1999). 
With its Latin title, Ducatus Iuliacensis, Clivensis et Bergensis, and bilingual captions in Dutch and French, his 1610 news map of Jülich, printed by David de Meine in Amsterdam, was obviously meant for the international market (Figure 15.1). Van Geelkercken probably made this particular map in Amsterdam, since it was based not on fieldwork, but on existing examples by Mercator. Done in the decorative style introduced by Hondius, with portraits of the main contestants in the Jülich crisis in the border, this map was unlike every other news map Van Geelkercken later made. Another 1610 map of the region, however, was original and 'to the life': this was a real news map that represented the actual situation with a high degree of accuracy (Figure 15.2). This map and later ones, as we shall see below, were in all likelihood based on his own fieldwork.

The first Jülich crisis was short-lived, and although Van Geelkercken published another map of Jülich with Dutch texts in 1610, he did not live off his news publications. More important, financially, was the commission for a town

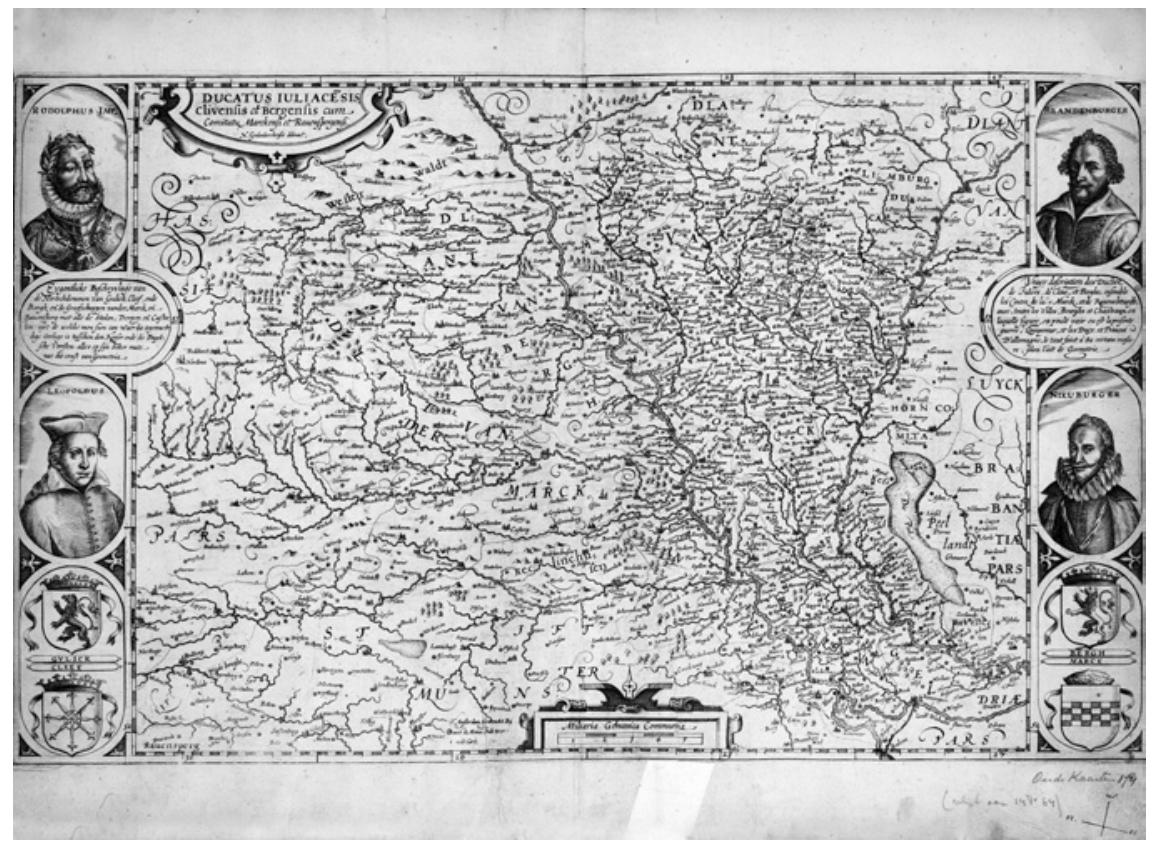

FIGURE 15.1 Nicolaes van Geelkercken. Ducatus Iuliacensis, Clivensis en Bergensis cum Comitatu Marckensi et Ravenspergensi (Amsterdam: David de Meine, 161o). The duchies of Julich, Cleves, and Berg, with portrait cartouches showing the main contenders in the Julich-Cleves controversy: Rudolph II, Archduke Leopold, Elector Johann Sigismund of Brandenburg and Elector Wolfgang Wilhelm von Pfalz Neuburg. Permission Amsterdam University Library 


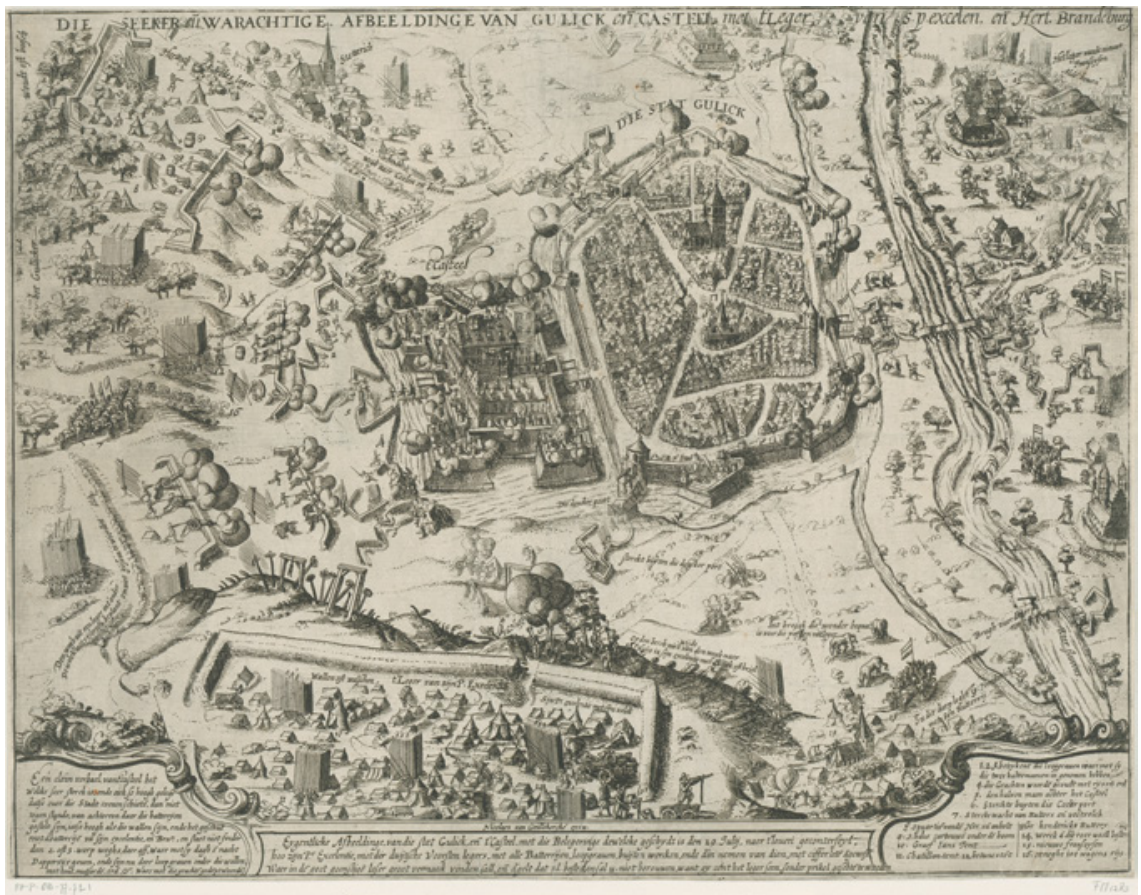

FIGURE 15.2 FM 1283: Nicolaes van Geelkercken. Afbeelding van Gulik naer't leven geconterfeyt (Amsterdam, 1610). Specifying all kinds of details, including particular trees and bridges, this 1610 print of the siege of Julich was based on fieldwork. Permission Rijksmuseum, Amsterdam

plan of Aachen, for which he received 300 guilders from the Aachen magistrate in December $1610 .{ }^{21}$ Since Aachen was only a day's travel removed from Jülich, Van Geelkercken probably secured the commission while returning from the warzone in the German borderland. For Van Geelkercken, work on civic projects and news publications would continue to infuse each other. This appeared again in 1611, when Van Geelkercken, having returned to Amsterdam, used his fresh knowledge of Aachen for a news print depicting the Protestant revolt that had erupted there after he left. ${ }^{22}$

Throughout his Amsterdam years, Van Geelkercken seems to have taken on every job he could, making the most of coincidental meetings and

\footnotetext{
21 Meurer, 'De jonge Nicolaes van Geelkercken', p. 44.

22 Warachtige afbeeldinge van de nieuwe oorloghe binnen der stadt Aken tegen de Magistraet en de Jesuwijten geschiet den 5. Julius 1611 (Amsterdam: Nicolaes van Geelkercken, 1611), in: Meurer, 'De jonge Nicolaes van Geelkercken', p. 44.
} 
circumstances. When an unknown German customer entered Van Geelkercken's Amsterdam shop with the request to engrave a drawing he had brought, Van Geelkercken did not feel the job was beneath him, taking it on for 12 guilders. ${ }^{23}$ Yet behind such chance encounters, a pattern emerges of a man with a keen eye to combine cartographical commissions with the short-term opportunities provided by circumstance. Thus, while working on a series of maps for Ubbo Emmius' history of Frisia, in 1614-15, he also engraved a number of portraits of Frisians, which he later sold in his shop. ${ }^{24}$ News prints, including maps, but also portraits and allegories, were one consistent and prominent element on his list from 1610 onwards, and would remain so until 1624.

Van Geelkercken was not the only cartographer who developed an interest in the news in this period. The fields of cartography and news publishing were overlapping to a considerable extent in the early seventeenth century. Both Pieter van den Keere, who translated Broer Jansz' Dutch corantos into English in the early 1620s, and Claes Jansz Visscher were trained mapmakers who matured into all-round (news) publishers. Jan Jansz sr., who established the first coranto in Arnhem in 1620, was also a noted cartographer. The father of the famous cartographer known by his Latinized name, Johannes Janssonius, Jansz sr. cooperated with Jodocus Hondius on the Atlas Minor. It is important to stress that in all these cases, the interest in cartography preceded the interest in news. As in Van Geelkercken's case their news publications were spinoffs of cartography rather than the other way around.

Cartographers, then, were well placed to become news publishers. They owed this in the first place to the versatility and profitability of their trade. Cartography was all the rage in the early seventeenth-century Republic, especially in Amsterdam. Pieter van den Keere's 1623 inventory shows that maps were the bulk of his produce and that he expected to sell more maps than other kinds of prints. ${ }^{25}$ Thriving shops appeared in the 1610 s that similarly focused on mapmaking - Blaeu, Visscher, Hondius/Janssonius - which laid the foundations for enduring publishing dynasties. Cartographers had the advantage of being able to supply a variety of clienteles. While the naval industry and military and civic authorities had obvious practical needs for maps, cartography also attracted a wider public interested in maps for their newsworthiness, their

\footnotetext{
23 Orenstein, 'Print Publishers', p. 167.

24 Ubbo Emmius, De Frisia et Frisiorum Republica (Leiden: Elzevier, 1616); Hollstein, Hollstein's Dutch \& Flemish etchings.

25 Kolfin, 'Amsterdam', p. 44.
} 
commemorative function, and their decorative qualities. ${ }^{26}$ Van Geelkercken practiced cartography in this broad sense, until chance again intervened.

As the Jülich crisis resurfaced in 1614, Van Geelkercken's interest in news publication intensified. Again he set out to document Maurice of Orange's exploits in his home country, this time publishing an original, and highly accurate map charting the armies' movements (Figure 15·3).27 This was evidently a map of an eye-witness, and Van Geelkercken used his information position by

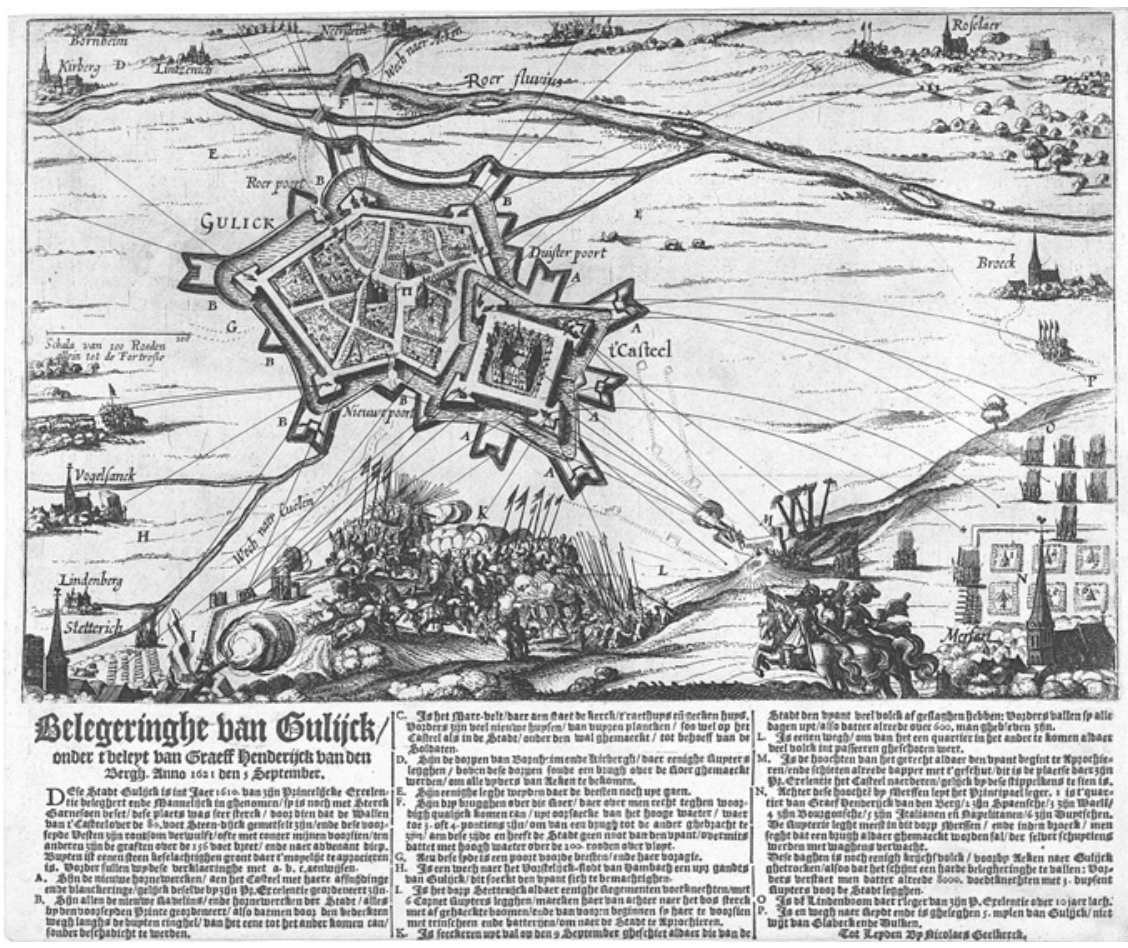

FIGURE 15.3 Nicolaes van Geelkercken, VVaere afbeeldinghe van den machtigen Tocht der beyder legeren (Amsterdam, 1614). Sold in Amsterdam, London, and presumably in Germany as well, this map by Van Geelkercken intended to show the movements of the armies as the Julich crisis rekindled in 1614. Permission Herzog August Bibliothek, Wolfenbüttel

26 J.F. Heijbroek and M. Schapelhouman, eds., Kunst in kaart. Decoratieve aspecten van de cartografie (Utrecht: H\&S, 1989); Kees Zandvliet, Mapping for Money: Maps, Plans and Topographic Paintings and Their Role in Dutch Overseas Expansion During the 16th and 17th centuries (Amsterdam: Batavian Lion International, 1998), pp. 210-54.

$27 \quad$ Waere afbeeldinghe van den machtigen Tocht der beyder legeren onder het beleyt vanden Marquis Spinola ... ende syne excellentie Mauritius van Nassou (Amsterdam: Nicolaes van Geelkercken, 1614). 
adding an original news bulletin recounting the latest affairs. Speed was of the essence. One English pamphlet was "Translated out of a Dutch coppie printed at Amsterdam by Nicholas van Gelkerken, a few daies sithence, together with a bewtiful mappe [of] the Townes, Marches, Armies and Camps, even as at this instant they remaine" (emphasis added). ${ }^{28}$ This suggests that it was the map's topicality that constituted part of its attraction. In a static siege, a map depicting the positions of armies could indeed remain accurate for a relatively long period. In the case of the manoeuvring armies of Maurice and Spinola in Jülich, however, this emphasis on the 'instantaneity' of the maps was obviously an overstatement. Yet we should not discard the remark too easily. The wider public's ability to witness army movements at a distance was relatively new in early modern Europe, certainly in the quality provided by Van Geelkercken's generation of mapmakers. Accurate, up-to-date maps simply were the most sensational form of war news available, and the quickest ones to appear were sure to be distributed widely.

In his titles, Van Geelkercken therefore frequently emphasized both the accuracy and actuality of his maps, using words such as 'warachtig' (truthful) and 'teghenwoordigh' (present). In one of his maps of Jülich he remarked that it was "waarin de leser groot vermaeck vinden sall, end' 't gelt dat Ul. Besteden sal $\mathrm{u}$ niet berouwen, want gy cont het leger seen, sonder prikel geschoten te worden" ("drawn after life, in which the reader will find great entertainment. And you will not repent the money you'll spend, because you can see the army without danger of being shot".) ${ }^{29}$ This might be a joke, but still it accurately catches the sense that it was the compression of space and time that was the news cartographer's main selling point, allowing his customers to see the war from a distance..$^{30}$ At the same time, this is the tart comment of the war

28 Carolus Demetrius, Nevves from Gulick and Cleue. A true and faithfull relation of the late affaires in the countries of Gulicke, Cleue and Bergh, and what townes have certainely been taken aswell by Marquesse Spinola, as by Graue Maurice (London, 1615). The translator was Carolus Van Meteren, whose father, the famous historian, had moved to London in the sixteenth century, but who evidently maintained contacts in the Dutch Republic. Van Geelkercken had engraved a map of the Netherlands (Nova Germaniae Inferioris descriptio ... sculpente Nicolao Geilkerckio) for the 1614 edition of Van Meteren's History of the Netherlands. See: Emanuel van Meeteren, Historie der Neder-landscher ende haerder naburen oorlogen ende geschiedenissen, tot den iare M.VI.XII (The Hague: Jacobsz van der Wouw, 1614).

29 FM 1283. Afbeelding van Gulik naer't leven geconterfeyt (Amsterdam: Nicolaes van Geelkercken, 1610).

3o Cf. Brendan Dooley, 'Introduction', in Brendan Dooley, ed., The Dissemination of News and the Emergence of Contemporaneity in Early Modern Europe (Farnham: Ashgate, 2010), pp. 1-20. 
correspondent who, unlike his clients, knows the danger of travelling with the army first-hand.

To ensure reliable and up-to-date maps, Van Geelkercken accompanied the army during its summer campaigns. In one of his later lawsuits-he contested a number of them - witnesses told the court that Van Geelkercken's son Jacob had travelled with them to the siege of Breda "to draw it". ${ }^{31}$ Jacob continued his father's practices. According to Van Geelkercken himself, one of his pamphlets was written from the back of a cart in the army. ${ }^{32}$

As he did in 1614, Van Geelkercken at least occasionally profited from his position in the army by doubling as an army correspondent. In 1622, for the siege of Bergen op Zoom, he had a full-blown media strategy. First, he published a newsletter from the army reporting the surprising beginning of the siege. ${ }^{33}$ As the siege developed he published two news maps, one during the siege, another directly after Maurice had liberated the town. ${ }^{34} \mathrm{He}$ followed up with an army journal describing the events that had taken place in the past weeks. Since this Journal was written for the Leiden secretary, it is tempting to conclude that Van Geelkercken had also provided the Leiden magistrate with handwritten newsletters during the siege. ${ }^{35}$ We know that various civilians travelling with the army worked as paid informers. The well-known poet and Shakespeare adapter Jan Starter, with whom Van Geelkercken cooperated early in his career, signed a contract with the Amsterdam courantier Broer Jansz when he entered Mansfeld's army as a chronicler in 1625 , promising that he would send Jansz the latest news from the army every week for two years. ${ }^{36}$ Van Geelkercken's connection with the Leiden magistrate and his published newsletter suggests a similar sort of agreement, but in the absence of archival proof this remains speculation. Whether or not he made the same arrangements as

\footnotetext{
$31 \quad$ Van der Meulen, 'Nicolaas Geylkerck', p. 64.

$32 \quad \mathrm{Kn} .3304$, Optocht der Princen, alles voorseyt inden Italiaenschen waersegger (1622).

33 Der princen post ruyter, advertiert het innemen van Steen-berghen, met het belegh van Berghen op Soom (Leiden: Nicolaes van Geelkercken, 1622).

34 The newsmaps are: FM 1465. Belegeringe van Bergen op zoom (Leiden: Nicolaes van Geelkercken, 1622) and FM 1469. Afbeeldinghe Vande Belegeringe ende 't Ontzet van de Stadt van Berghen op Zoom, noyt subyter, noch wonderlijcker veranderinghe gheschiet, op den tweeden October des Jaers A. 1622 (Leiden: Nicolaes van Geelkercken, 1622).

$35 \mathrm{Kn} .3340$. Iournael ofte dagh-register, waer in vertoont werdt des vyandts scherm-slagh voor Berghen op zoom: met het dapper verset ofte ontset, der selver stee (Leiden: Nicolaes van Geelkercken, 1622), sig. A4v.

36 They worked together when Van Geelkercken was in Friesland in the 161os. J.H. Brouwer, Jan Jansz Starter (Assen: Van Gorcum \& Comp, 1939), p. 45.
} 
Starter, however, the siege shows that Van Geelkercken's main interest was always to make drawings, while news reporting was a spin-off.

Van Geelkercken was a private entrepreneur, who was not on the army's payroll. The only map which was certainly commissioned by the army was his map of the siege of Breda (Figure 15.4). Like other official military maps, this was a collaborative project. Van Geelkercken and his fellow-cartographer Van Bergen produced the original drawing, now in the National Archive in The Hague, as an ordnance map for the Prince of Orange. ${ }^{37}$ It was printed for the general public, while retaining all the original detailed information for military use. Although the map is rather large for a news map, Van Geelkercken and Van Berghen nevertheless emphasize its topicality and newsworthiness, and provided colourful details on the "present" situation (the village of Rozendaal,

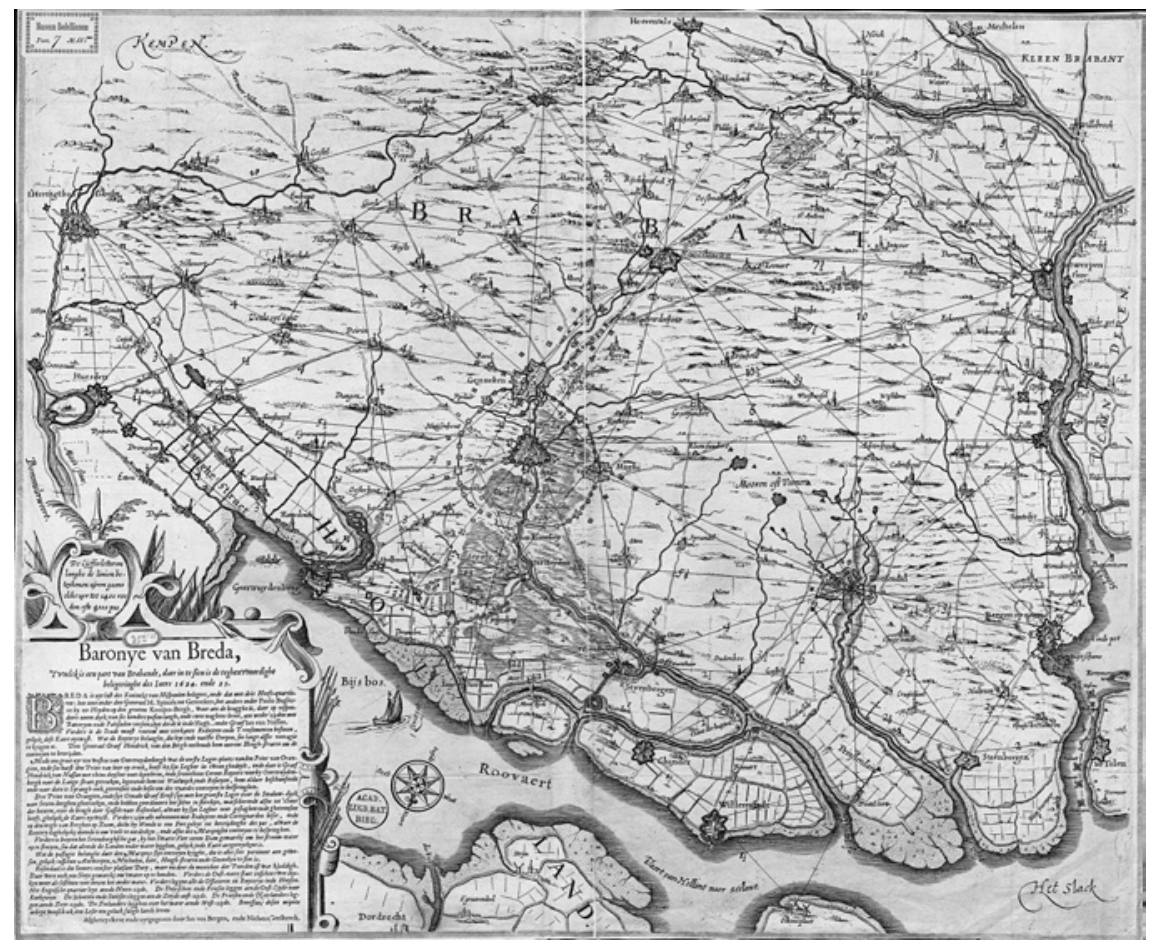

FIGURE 15.4 FM 1520. Barony van Breda, 't welck is een part van Brabandt, daer in te sien is de teghenwoordighe belegheringhe des Iaers 1624 ende 25. (Nicolaes van Geelkercken en Jan van Bergen, 1625). An accurate ordnance map produced during the siege of Breda. Permission Leiden University Library 
for instance, was described as a beautiful village, "though currently a bit messy" because of the many horses). ${ }^{38}$

Army cartographers such as Van Geelkercken worked on a freelance basis without a fixed salary. Rather, the government or the army would guarantee to buy a number of prints at a good price. Balthasar Florisz van Berckenrode, the only Dutch army cartographer whose case has been studied, "got 336 gulden for twenty-eight copies of his Breda map from the authorities", that is, twelve guilders for each print. And surely that was not all. Berckenrode made many official memorial maps for the Prince's campaigns until his death in 1616 . Often dedicated to the Prince, these must have earned him generous rewards. Moreover, the Prince of Orange probably encouraged the dissemination of the maps of his victories. Despite his privileged position Berckenrode suffered from financial problems. ${ }^{39}$ Van Geelkercken, less privileged, but also less invested in the genre, never seems to have had such problems. ${ }^{40}$ Although lacking Van Berckenrode's privileges, Van Geelkercken did receive money for his maps from officials. It is clear that he regularly sent his work to lower magistrates, with at least occasional success. He received 48 guilders from the city council of Bergen op Zoom, in 1619, and a two-pound gratuity from the Middelburg magistrate, in 1622, for his map of the siege of Bergen op Zoom. ${ }^{41}$ Yet unlike Berckenrode, Van Geelkercken could rely on a broad range of publications to supplement his income.

In the first place, he sold town plans, maps, and news maps in his shop, where he employed a young colourer, Pieter, for customers who desired a more decorative copy. ${ }^{42}$ Although the borders between the categories are not perfectly clear, there are differences between Van Geelkercken's news maps and Berckenrode's memorial maps. This can be illustrated by comparing Van Geelkercken's 1610 map of Jülich with the official siege map that Berckenrode made of the city in 1611. The date itself is the first major difference: whereas Van Geelkercken published his maps during the siege, Berckenrode produced

38 FM 1520. Barony van Breda, 't welck is een part van Brabandt, daer in te sien is de teghenwoordighe belegheringhe des Iaers 1624 ende 25.

Kees Zandvliet, 'Kartografie, Prins Maurits en de Van Berckenrodes', in Prins Maurits' kaart van Rijnland en omliggend gebied door Floris Balthasar en zijn zoon Balthasar Florisz. van Berckenrode in 1614 getekend, ed. Kees Zandvliet (Alphen aan de Rijn: Canaletto, 1989), pp. $17-50$.

40 Cf. the amounts of 1,00o and 1,400 guilders he paid for his house(s) in Th. H. Lungsing Scheurleer, et al., Het Rapenburg. Geschiedenis van een Leidse Gracht, vol. 5 (Leiden: Rijksuniversiteit Leiden, 1990), pp. 447, 454. I am grateful to Paul Hoftijzer for this reference. Van der Meulen, 'Nicolaas Geijlkerck', p. 63; Van Maanen, 'Nicolaas van Geelkerken', p. 245. Lunsingh Scheurleer, Het Rapenburg, p. 458. 
his after it had been won. Moreover, unlike Van Geelkercken's maps, Van Berckenrode's is large and expensive, with captions in French, the language of diplomats and army officers. These differences are typical for seventeenthcentury practice: news maps were made by various printers competing to be first during a war or siege. The official memorial engraving printed after the battle had been lost and won was bigger and designed to impress both contemporaries and posterity. ${ }^{43}$

During and immediately after campaign season, Van Geelkercken depended on his civic and military cartographical projects, and his occasional army news. Winter was silly season, however. Surveying projects were impossible, and the seasonal nature of early modern warfare dictated that there was no war news to be had. Van Geelkercken therefore sought other ways to capitalize on the news. As we shall see, his list contains various winter spin-offs of his summer work, some of which were tremendously successful.

\section{A New Town, New Genres: Chronicles and Almanacs}

After Van Geelkercken had had his own press in Amsterdam for a couple of years, he moved to Leiden, where he hired a house on the Rapenburg, in 1616.44 The move was probably related to his working relationship with the historian and cartographer Petrus Bertius, and his subsequent cooperation with Philippus Cluverius, a German geographer, who was appointed to the chair of geography in the same year. ${ }^{45}$ Van Geelkercken worked with Cluverius on his Germanice antiquce libri tres (1616), for which he engraved a series of pictures of warriors and maps, and might have expected more assignments from the new professor (which did indeed arrive). ${ }^{46}$ In any case it is clear that Van Geelkercken saw healthy business opportunities. Owing to its flourishing university, Leiden offered a great market for all kinds of books, including news. ${ }^{47}$ Scholars like Cluverius wanted their books illustrated, and students from all over Protestant Europe thirsted for information on the beginning of the Thirty Years War.

43 See, for example: David Kunzle, From Criminal to Courtier: The Soldier in Netherlandish Art, 1550-1672 (Leiden: Brill, 2002), p. 453.

44 Lunsingh Scheurleer, Het Rapenburg, p. 447.

45 On Cluverius: Peter Fuchs, 'Clüver, Philipp', in: Neue Deutsche Biographie, 3 (1957), p. 295.

46 Philippus Cluverius, Germanice antiqua libri tres (Leiden, 1616). It is striking that Van Geelkercken's Leiden activities come to a halt soon after Cluverius' death, in 1623 .

47 Cf. Benjamin Roberts, Sex and Drugs before Rock ' $n$ ' Roll: Youth Culture and Masculinity During Holland's Golden Age (Amsterdam: Amsterdam University Press, 2012), pp. 130-1. 
Van Geelkercken was more than willing to cater for them. In Leiden he experimented with various new genres that allowed him to make the most of the war news he gathered. He thrived: in 1621, he bought part of the house he had rented, and rented another. ${ }^{48}$

The first by-products of the news, of course, were chronicles offering an overview of the year's news, or newsbooks. This genre, based on the German Messrelationen, was far from new, but Van Geelkercken was one of the first Dutch publishers to capitalize on the interest in the Thirty Years War by publishing newsbooks focused on the upheavals in the Holy Roman Empire. Possibly inspired by the success of Wassenaer's Historisch Verhael ("Historical Narrative", 1622-35), Van Geelkercken published his first newsbook, on the risings in the Veltolin, in $1621 .{ }^{49} \mathrm{~A}$ map of the region, made by Cluverius and engraved by Van Geelkercken himself, could be bought in his shop separately.50 It was probably successful, for Van Geelkercken repeated the format. On the title page of his 1623 War Memorial, Pope and Emperor literally open up the stage of Germany, showing all the "new wars" that had been reported in the past year. The main text provided a month-by-month overview of events, illustrated by crude versions of Van Geelkercken's larger maps. And although the title page also advertised news from France and England, they received only very brief mention on the final page, where Van Geelkercken wrote that: "we have said on the title page [that we would report] on France. To do so is unnecessary, however, for peace has been concluded in the past year". ${ }^{51}$ Van Geelkercken traded in war, and the most memorable war, in the early $1620 s$, occurred in Germany. But there was another reason to focus on the Holy Roman Empire. In both cases, the newsbook seems to have functioned as a by-product of his summer maps. As a born German and a partner of Cluverius, Van Geelkercken sold maps of the Holy Roman Empire and The Netherlands, not of France and England, on which he probably had little information.

Another obvious genre to which the printer of war news might turn in silly season was the almanac, traditionally published in December and January. ${ }^{52}$ I have found previously unknown evidence that Van Geelkercken introduced

48 Lunsingh Scheurleer, Het Rapenburg, p. 447.

49 Rhaetiae dat is: 'tlant vande Grisons ende Veltolijn (Leiden: Nicolaes van Geelkercken, 1621).

5o Philippus Cluverius and Nicolaes van Geelkercken (engr.) Alpinae seu foederatae Rhaetiae Subditarumque ei terrarum nova descriptio (Leiden: Nicolaes van Geelkercken, 1621). This map was later reproduced in Janssonius' Theatrum Imperii Germanici (1632).

$5^{1} \quad$ [Van Geelkercken], Ghedenckwaerdige Historie ende Krijghs-Memorie (Leiden: Nicolaes van Geelkercken, 1623), p. 56.

$5^{2}$ On Dutch almanacs, see Jeroen Salman, Populair drukwerk in de Gouden Eeuw (Zutphen: Walburg Pers, 1999). 
one of the most successful formats of the century, The Italian Prophesier (De Italiaense Waer-segger). He published the first edition of this title in 1621, and continued it at least until $1624 .{ }^{53}$ However, since the successful title was soon imitated by other Dutch publishers, new editions appeared throughout the seventeenth and even well into the eighteenth century. ${ }^{54}$ Van Geelkercken's initial editions were also translated into English, at least in 1622 and $1624 .{ }^{55}$ An ephemeral trifle compared to his cartographical work, the Italian Prophesier ironically was Van Geelkercken's most lasting contribution to Dutch print culture.

The series claimed to be based on the papers of the Bolognese mathematician and cartographer Giovanni Antonio Magini. Today, Magini is mainly remembered for his magisterial atlas Italia (1620), as well as for the fact that he beat Galileo to the chair of mathematics at the University of Bologna. In his time, however, Magini was also a noted astrologer, and although it is clear that not a word of the Prophesier was actually translated out of Italian, his name alone sufficed to provide the almanac with an air of authority and exoticism.

There are two main reasons to suppose that the Leiden almanacs, hitherto catalogued as anonymous, were both published and written by Van Geelkercken himself. In the first place, there are cross-references with his other works. Van Geelkercken asserted the accuracy of the Prophesier's prognostications in one pamphlet in which he compared what had happened with what had been prognosticated in the Prophesier. ${ }^{56}$ The Prophesier in turn advertised histories that bear Van Geelkercken's name on the title page. This clearly suggests that he was involved in publishing the work, but one might still have doubts as to his authorship.

The strongest indication that Van Geelkercken was also involved in writing the almanacs occurs in the preface to the 1622 edition, where the anonymous

53 The only surviving copy of the 1621 edition is kept in the Leiden University Library, THYSPF 2759. Den Italiaenschen vvaerseggher, dat is een prognosticatie, op het iaer onses Heeren 1621 (Leiden: Nicolaes van Geelkercken, 1621). Kn. 3303, Den Italiaenschen vvaerseggher, dat is een prognosticatie, op het iaer onses Heeren 1622. After 1624, the booklets change their title and appearance, and probably move to other printers.

54 On the (influence of) Den Italiaenschen waerseggher, see Salman, Populair drukwerk, pp. 222-3, 242-3. Salman discusses the text as anonymous.

55 STC 17182. The Italian prophecier. That is, A prognostication made for the yeere of our Lord God 1622 ... Faithfully translated out of Italian into Dutch, and now into English (London, 1622); STC 17183. A strange and wonderfull prognostication (London, 1624).

56 Salman, Populair drukwerk, p. 223n. states that Kn. 3304, Optocht der Princen, alles voorseyt inden Italiaenschen waersegger (1622) was critical of the Prophecier. Yet although the pamphlet begins listing the things that have not come to pass, the author discovers the truth of the prognostications at the end of the pamphlet. 
author claimed to have been taught by the great Magini, learning "various things which I daily find to be in accordance with the truth". ${ }^{57}$ This assertion can only refer to Van Geelkercken's own biography. Recent work in the history of cartography has shown that Van Geelkercken was a brother to Arnoldo di Arnoldi, a cartographer and engraver who made many maps for Magini in Bologna. ${ }^{58}$ From 1599 onwards, Arnoldo was assisted by his brothers Jacob and Nicolaes. ${ }^{59}$ Before he arrived in Amsterdam in 1604, then, Van Geelkercken received his training as a cartographer, and probably also as an astrologer, in Magini's workshop. Van Geelkercken might therefore have introduced Magini's magnum opus Italia to the Amsterdam booksellers. It is unknown to whom he was apprenticed during his early years in Amsterdam, but the most likely candidates, Blaeu and Hondius, also happen to be the earliest reproducers of Magini's maps of Italy. ${ }^{60}$

Van Geelkercken's strong connections with Magini explain why various details given in the preface of his almanac are actually true. For example, the author of the almanac says that Magini's papers were given to him by his son Fabio. ${ }^{61}$ The statement is probably a ruse, meant to provide his text with an aura of authenticity. The son's name, however, is correct. Rather than copying Magini's astrological works, then, Van Geelkercken copied his business model, using the affinities between cartography and astrology to deploy his skills and knowledge in the winter, and to widen his clientele. The seasonal nature of (war) cartography led him, like Magini, to dabble in other genres.

57 Kn. 3303. Den Italiaenschen waerseggher (1622), sig. A1v.

58 Henk van der Heijden, 'Wie was Arnoldo di Arnoldi?', Caert-thresoor, 18.2 (1999), pp. 37-40.

59 Meurer, 'De jonge Nicolaes van Geelkercken', 43. See also: Roberto Almagia, L'Italia' di Giovanni Antonio Magini e la cartographia dell'Italia nei secoli XVI e XVII (Naples: Perrella, 1922), pp. 17-18, 162-7. Almagia shows that Jacob and Nicholas, the youngest brother, were in Bologna until 1603, when their brother Arnoldo died in Rome. After their departure, another Dutch engraver, 'Amadeo Giovanni di Amsterdam' took their place. The information derives from Magini's preface to his Tavole del Primo Mobile.

6o Magini's cartographical work was reproduced by various Amsterdam workshops in the seventeenth century. Blaeu $(1614,1616)$ and Hondius $(1617,1620,1632)$ were the first, Claes Jansz Visscher (1650) followed later. See: Orietta Lago Selva, 'Giovanni Antonio Magini's Italia', in Imago Italiae. Fabrica dell'Italia nella storia della cartografia tra medioevo ed eta moderna: realtà, immagine ed immaginazione dai codici di Claudio Tolomeo all'atlante di Giovanni Antonio Magini, ed. Luciano Lago (Trieste: Edizioni Università di Trieste, 2002), pp. 675, 737 .

61 Kn. 3303. Den Italiaenschen waerseggher (1622), sig. Aiv. 


\section{Infotainment: The News Novel}

Both the almanac and the yearly newsbooks were obvious and profitable by-products for those involved in war publication: they provided them with work in the winter, while stimulating the news hunger of their clients. At the same time, these winter fruits show that Van Geelkercken approached news as a form of entertainment. To him, the almanac was a kind of puzzle, and figuring out its relation with the unfolding news story a game that could be played throughout the year. The lines quoted above, in which he emphasized not only the topicality of one of his maps, but also the enjoyment it provided, show his desire to entertain, and to blend literary and non-literary forms.

For Van Geelkercken, news, like literature, could cause terror and delight in his audience. Even in one of his dedicated news pamphlets, the Journal of the siege of Bergen op Zoom, he combined information and entertainment. Starting with a poem, and a short historical introduction, he quickly proceeded to the news, observing that "the reader desires the present more than the past". ${ }^{2}$ Illustrated with his own engravings of the siege, the pamphlet ended, characteristically, with a series of "farcical observations", funny short stories about the soldiers' lives in the camps. Fusing the categories of history, news and farce, Van Geelkercken here went through a well-deliberated sequence. Starting with the most serious genre, he ended with comic relief to restore the humoral balance of his readers.

The fictionalizing twist to the news given in the Journal was followed by another original enterprise. The Wonderful Adventure of Two Beloved, which Van Geelkercken published together with an edition of the Italian Prophesier in January 1624 , is unique in its kind. ${ }^{63}$ Besides being the first original novella in the Dutch language, it is also a fictionalized news story, in which Van Geelkercken reflected on recent events in the Thirty Years War by describing in simple prose the journey of two lovers, the soldier Waterburn and the young girl Wintergreen.

Barred from marriage by Wintergreen's parents, Waterburn enlists in an army raised by Colonel Frenck, a Bohemian envoy who had indeed raised an Dutch

62 Kn. 3340, Iournael ofte dagh-register, waer in vertoont werdt des vyandts scherm-slagh voor Berghen op zoom: met het dapper verset ofte ontset, der selver stee (Leiden: Nicolaes van Geelkercken, 1622), sig. A4v. 'den Leser [verlangt] meer nae het teghentwoordighe, als na het ghepasseerde'.

63 Grootes, Wonderlicke avontuer, edited the pamphlet (without the almanac) because it is the first original novella in the Dutch language. 
army for Frederickv in $1619 .{ }^{64}$ Soon afterWaterburn has departed, Wintergreendesperate without her lover-cross-dresses and also enlists. After much ado, she finds him in an army bed: they have been assigned to the same house. Waterburn does not recognize her-and falls asleep. Chastity, Geelkercken tells us, does not allow him to convey her thoughts at that moment. Her moaning wakes Waterburn up, though, and once he knows the truth, "Cupid's bow stood ready with an arrow". She soon gets pregnant, and then sees him die in the battle at White Mountain. Of course he is not dead-he even manages to save Frederick v-but they do become separated again. Waterburn then fights at Bergen op Zoom (where Van Geelkercken, as we have seen, had been present himself), and she, in mourning, travels to the West. It is there, a shipwreck or two later, that they meet again, make their fortune, and live happily ever after.

Resembling the French sentimental novellas of the period, the story is rather unremarkable. ${ }^{65}$ But the novella is important because it shows how van Geelkercken both repackaged and marketed the news. It fits Van Geelkercken's strategy to reuse the news of the Thirty Years War, some of it only weeks old, to entertain and instruct his readers. Instruct, because the story is also an allegory of Dutch Protestantism. The Dutch, like Waterburn and Wintergreen, had wandered into the terrible German wars to help the Winter King, Frederick v. After the devastating defeats of the Protestants in Germany, hope seemed bleak, but God, The Wonderful Adventure implies, has predestined the Dutch to glory in the West Indies. Such an allegorical reading is suggested by the way in which Van Geelkercken advertised his novella: "With this", he wrote, "comes a miraculous adventure of Mr Waterburn and Winter-Green, and I hope that as all their sorrows and torments have now turned into happiness and prosperity, the next year, too, will turn from sadness into joy"(emphasis added). ${ }^{66}$

Like his chronicles, Van Geelkercken's novel was recounting the recent history of the Thirty Years War. Like his almanacs, it anticipated the news of the coming year, in this case the arrival of good news from America. Of course, Van Geelkercken's readers could rely on him for coverage of the projected recovery of the Protestant cause. Later in the year, news arrived that the Dutch had conquered Salvador de Bahia in Brazil. Sadness now indeed seemed to have turned into joy, and Van Geelkercken responded by publishing Reys-boeck van het rijcke Brasilien ("Travelbook of Rich Brazil") in which he offered not only a short summary of the news of the conquest, but also a description of the

\footnotetext{
64 Joseph Polisensky, Tragic Triangle: The Netherlands, Spain and Bohemia, 1617-1621 (Prague: Charles University, 1991), pp. 109-29, 198-238.

65 Grootes, Wonderlicke avontuer, pp. 16-17.

66 Italian Prophecier (1624), sig. Aur.
} 
conquered land illustrated with his own maps. ${ }^{67}$ Again, he blended news with history and cartography so as not to be dependent on topicality alone.

\section{Van Geelkercken in Protestant Print Networks}

The book market in which Van Geelkercken operated was highly competitive. In the absence of a guild, publishers and booksellers pirated each others work, and new successes were quickly imitated. But even competitors often cooperated, and Van Geelkercken seems to have had a solid network of colleagues, especially in Friesland and Amsterdam, with whom he frequently cooperated. ${ }^{68}$

In Friesland, where Van Geelkercken worked on the Ubbo Emmius maps, he befriended the engraver Pieter Feddes, and cooperated with the bookseller Jan Jansz Starter. Back in Amsterdam, he was particularly close to Jodocus Hondius, with whom he cooperated on various occasions and who might have become his tutor when he arrived in the city in 1604. In 1614-15, when Van Geelkercken owned his own bookshop in Amsterdam, Hondius' son Henricus hired Nicolaes to map the Veluwe region in Guelders for his wealthy client Jan van Wely, Maurice of Orange's ill-fated jeweller. ${ }^{69}$ Other projects, too, were done in cooperation with Hondius' circle. Van Geelkercken's map of the world, Orbis terrarum descriptio duobis planis hemisphaeriis comprehensa was engraved in 1617 by Johannes Janssonius, Hondius' son-in-law. It was an enduring connection. In 1632, Janssonius reproduced several of Van Geelkercken's news maps in his Theatrum Imperii Germanici. ${ }^{70}$ But it was not only the Hondius family with whom he worked. Petrus Bertius, with whom Geelkercken worked on his Nova Germaniae Inferioris (1614), was originally a Flemish refugee related to Hondius. One of his engravings was published by Claes Jansz Visscher during his Amsterdam period. ${ }^{71}$

67 See Michiel van Groesen, 'A Week to Remember. Dutch Publishers and the Competition for News from Brazil, 26 August-2 September 1624', Quaerendo, 40.1 (2010), pp. 26-49, at 45-6. See also: Kn. 3540, Reys-boeckvan het rijcke Brasilien, Rio de la Plata ende Magallanes, daer in te sien is, de gheleghentheyt van hare landen ende steden (Dordrecht: printed by J. Canin for Nicolaes van Geelkercken, 1624).

68 On the cooperation between printers, see Kolfin, 'Amsterdam' and Henk Borst, 'Van Hilten, Broersz en Claessen: Handel in boeken en actueel drukwerk tussen Amsterdam en Leeuwarden rond 1639', De Zeventiende Eeuw, 8.2 (1992), pp. 131-6.

69 Doornink-Hoogenraad, Nicolaes van Geelkercken, p. 27, no. 57.

$70 \quad$ For example his map of Rhaetia (1621) and Jülich (1610).

71 Hollstein, 7: 92. Nicolaes van Geelkercken (engr.), Portrait of William I, Prince of NassauOrange (Amsterdam: Claes Jansz Visscher, 1615). 
When Van Geelkercken moved to Leiden, he continued to profit from his Amsterdam connections. Within cities, competition and cooperation went hand in hand. Between different cities, however, cooperation between booksellers and publishers was the rule. An intricate network of exchange between booksellers took shape in the seventeenth century, in which news, too, was frequently exchanged..$^{72}$ One of the rare surviving correspondences between printers in this period shows that Van Hilten sent copies of his coranto to the Leeuwarden bookseller Tjerck Claessen every week. ${ }^{73}$ Although such archival proof is lacking in Van Geelkercken's case, it is clear that he frequently exchanged material with his Amsterdam colleagues. Thus one of his 1620 Leiden news maps could be bought in Van Hilten's shop, 'The Crowned Hat', for instance, which indicates a cooperative venture. ${ }^{74}$ In the same year, Joris Veselaer printed another of Van Geelkercken's news maps for him, which could also be bought in his shop. ${ }^{75}$

It may have been Van Geelkercken's Amsterdam colleagues who distributed his maps and almanacs to England. Veselaer, after all, was the 'George Veseler' who printed the first English corantos, translated from the Dutch by Van der Keere (Hondius' brother-in-law), in the 1620 . Hondius himself, moreover, had lived in exile in London before he settled in Amsterdam in $1595 .{ }^{76}$ There may also have been other intermediaries, as Hondius had many ties with Flemish exiles and Englishmen in the booktrade such as the print dealer Hans Woutneel. ${ }^{77}$ Possibly through Hondius, Van Geelkercken also had his own contacts in England. His 1614 London map of Jülich was printed by Carolus Demetrius, the son of Emmanuel van Meteren, for whose history of the Low Countries Van Geelkercken had engraved a map two years earlier. ${ }^{78}$ In a trial of 1641 , Van Geelkercken claimed that his son Jacob had trained as a geographer in England,

72 See e.g. Harline, Pamphlets, pp. 82-91.

73 Borst, 'Van Hilten, Broersz en Claessen'.

74 Jacob van Lennep and J. ter Gouw, De uithangteekens, in verband met geschiedenis en volksleven beschouwd, vol. 2 (Amsterdam: Gebroeders Kraay, 1868), p. 215.

75 FM 1429. Afbeeldinghe van de Berchemer-waert, ofte Papen-Bril schants, met het innemen van Bacharach, ende een bewijs hoe Spinola met water ende sweert gheslaghen is gheweest (Amsterdam: Joris Veselaar, voor Nicolaes Geelkercken, 1621).

76 Peter H. Meurer, 'The Cologne Map Publisher Peter Overadt (fl. 1590-1652)', Imago Mundi, 53.1 (2001), pp. 28-45, at 4on.

77 R.A. Gerard, 'Woutneel, de Passe and the Anglo-Netherlandish Print Trade', Print Quarterly, 13 (1996), pp. 363-76; Ilja Veldman, Images for the Eye and Soul: Function and Meaning of Netherlandish Prints (1450-1650) (Leiden: Primavera Pers, 2006), p. 280.

78 Van der Meulen, 'Nicolaas Geijlkerck', p. 55. Van Meteren probably knew Hondius when both them were in exile in London. 
which also suggests a direct connection. ${ }^{79}$ Whether Van Geelkercken traded with English booksellers directly or through intermediaries, however, his work was sold in England because of the Protestant diaspora of booksellers set in motion by the Revolt. ${ }^{80}$

The overriding correspondence between Van Geelkercken's contacts, and indeed between most news publishers during the years of his activity, is that they were all solidly Orangist, and dedicated supporters of the contraremonstrant cause. Claes Jansz Visscher was a contraremonstrant, and so were the army dependents Broer Jansz and Caspar van Hilten. ${ }^{81}$ Hondius, an Antwerp refugee, was even a contraremonstrant ringleader. ${ }^{82}$ Even Van Geelkercken's German customers and collaborators such as Emmius and Cluverius were staunch supporters of militant Calvinism. Van Geelkercken himself, both immigrant and army dependent, was no exception.

Like most news printers in this period, Van Geelkercken therefore exclusively printed news from a contraremonstrant and Orangist perspective. Besides reporting Maurice's exploits in the Lower Rhine region, he engraved and printed portraits of the princes of Orange in the 1610s, celebrated their main victories, and engraved prints that were vehemently against the Truce with Spain (see Figure 15.5). He reported triumphantly on the Synod of Dordt, in 1618, and after Maurice's purge of town magistrates ('wetsverzetting'), in the same year, Van Geelkercken published an official Leiden 'coranto' listing the city's new council members. ${ }^{83}$ Relishing the demise of the remonstrants, he also published copies of similar corantos from other cities. ${ }^{84}$

Various scholars of seventeenth century print culture have warned against supposing a too narrow relationship between the personal views of the publisher

79 Doornink-Hoogenraad, Nicolaes van Geelkercken, p. 12.

8o Ole Peter Grell, 'The Creation of a Transnational, Calvinist Network and its Significance for Calvinist Identity and Interaction in Early Modern Europe', European Review of History: Revue européenne d'histoire, 16 (2009), pp. 619-36; Hugh Dunthorne, Britain and the Dutch Revolt, 1560-1700 (Cambridge: Cambridge University Press, 2013), p. 54.

81 On the Protestantism of the early Dutch and English courantiers, see Göran Leth, 'A Protestant Public Sphere: The Early Modern Newspaper Press', Studies in Newspaper and Periodical History, 1.1-2 (1993), pp. 67-90.

82 Orenstein, 'Print Publishers', pp. 186-7, 195.

83 Kn. 2701. Courante der stadt Leyden also vande publicatie ende verkiesinghe des raets aldaer gheschiet (Leiden: Nicolaes van Geelkercken, 1618).

84 Authentyke copie van de verkiesinghe des magistraets persoone tot Rotterdam, met der zelver namen (Leiden: Nicolaes van Geelkercken, 1618); Publicatie ende verkiesinghe des raets tot Haerlem (Haarlem: Adriaen Roman for Nicolaes van Geelkercken, 1618). 


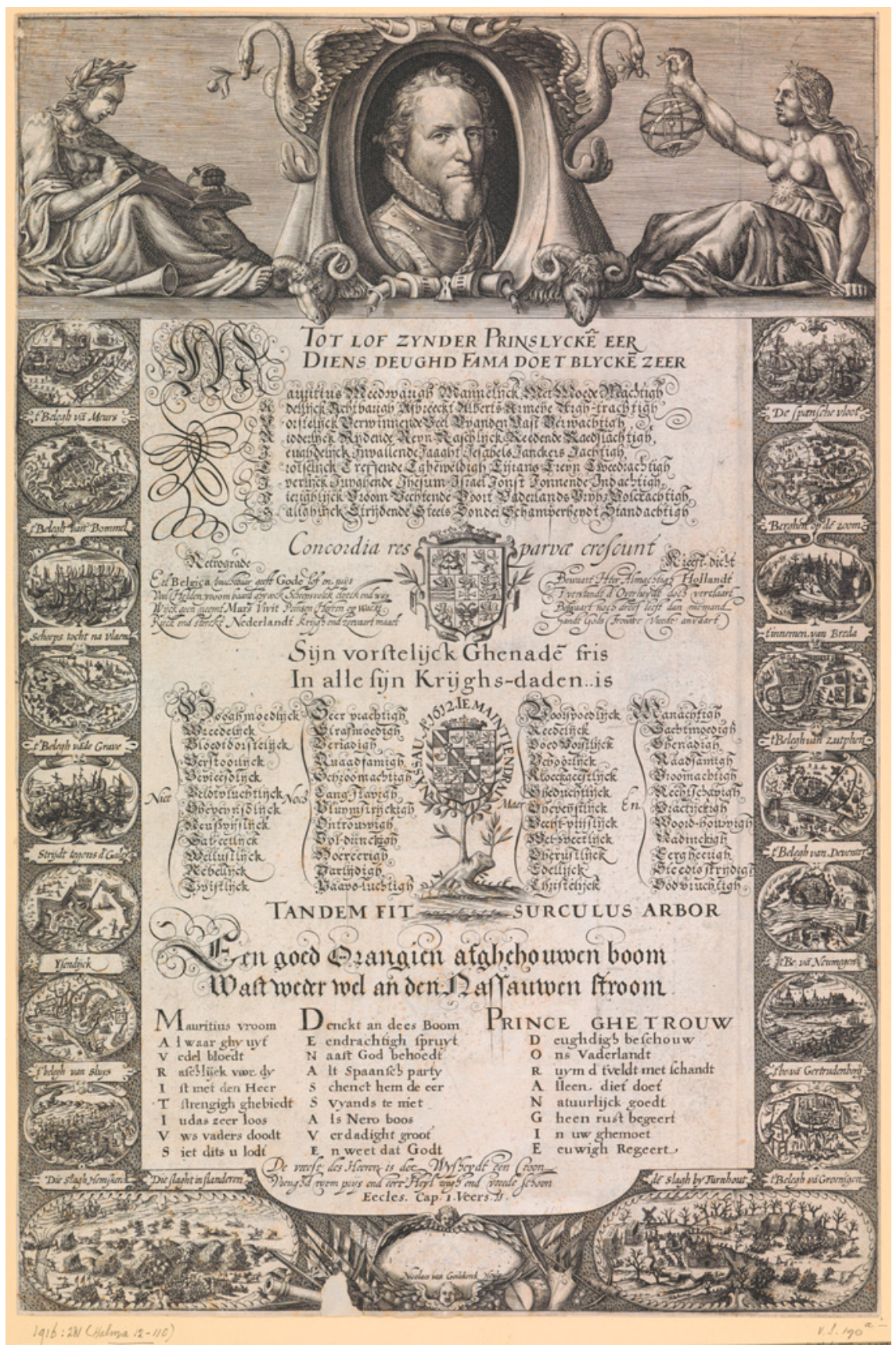

FIGURE 15.5 Geelkercken, Nicolaes van. Tot lof zynder Prinslycke(r) eer Diens deughd

Fama doet blycke(n) zeer (Leiden: Nicolaes van Geelkerck, 1612[?]). Portrait of Maurice of Orange with allegorical figures and depictions of his major victories. The date is doubtful because it is associated with Maurice rather than the print. Permission Rijksmuseum, Amsterdam 
and his output, ${ }^{85}$ and rightly so: few publishers scorned a quick profit even if that meant that the text published went against their political or religious conscience. The fierce contraremonstrant Hondius on one occasion even published a print of Rome with texts praising the Pope. ${ }^{86}$ Yet news, especially war news, should be seen as a separate category of print during the Truce. Hondius may have printed an occasional Catholic religious print, but he would never have printed a news print of a Catholic victory. Van Geelkercken's case illustrates that unlike the print market in general, the news business in the 1610 s and 1620 s was highly confessionalized and structured to a considerable extent by ideology. Shaped during the Dutch Revolt and dependent on army networks for both the all-important war news and commissions, the networks responsible for non-periodical news by necessity printed partisan news strongly biased towards Protestant internationalism. Considering the popularity of the Orangist and contraremonstrant cause, this was also a wise business choice.

\section{Conclusions}

Versatile, opportunistic, focused on the army, and unfailingly contraremonstrant and Orangist in his ideological outlook, Van Geelkercken was a typical news bringer, whose early career is not unlike those of the army courantiers Broer Jansz and Casper van Hilten. These army men, too, had access to valuable army news, and both their careers took off during the Truce with Spain. In the $1610 \mathrm{~s}$, this generation of printers started to transform a market dominated by news of the Revolt into a market for international, and especially German tidings.

Van Geelkercken's career shows that the seasonal nature of war news made special demands on newsmakers, and stimulated them to creatively recycle their news through genre diversification. It was by blending the categories of cartography, history, news and literary entertainment that Van Geelkercken showed his inventiveness and individuality. Despite the contingencies apparent in his list, there is a clear strategy underlying Van Geelkercken's news publications, especially in his Leiden period. While pursuing his mainly cartographical commissions he attempted to profit from the information that came his way. He increasingly experimented with remediation, publishing the same material on the same subject in different genres and formats, presumably to appeal to distinct audiences.

\footnotetext{
85 See e.g. Veldman, Images, p. 273.

86 Orenstein, 'Print Publishers', p. 195.
} 
Van Geelkercken's case illustrates the open and experimental character of the Dutch news market in its decades of expansion, when publishers could do news on the side, and try their luck in a variety of news genres. For Van Geelkercken and many others, news publishing started out as a profitable byproduct of his main trade, which he and they marketed in a wide range of genres. As the century progressed, and the market became parcelled up, however, there was an increasing need for specialization. Jansz and Van Hilten found their niche with the printed coranto, Visscher excelled in the newsprint, and Blaeu focused on the atlases. Van Geelkercken could or would not compete. In 1628, he became master surveyor for the province of Guelders, which offered a much more secure, stable and, presumably, comfortable life. In this too, he resembled many young men in the print business, for whom news was often a passing concern. 